\title{
The Effect of Partnership and Community Development Program on Financial Performance and Firm Risk: Evidence from Indonesian State-Owned Enterprises
}

\author{
Jasman Jasman $^{1}$ Sekar Mayangsari² \\ 1. Faculty of Economics and Business, Perbanas Institute, Jl. Perbanas, Karet Kuningan, Setiabudi, Jakarta \\ 12940. \\ 2. Faculty of Economics and Business Trisakti University, J1. Kyai Tapa No.1, Tomang, Grogol \\ Petamburan, West Jakarta, Jakarta 11440, Indonesia
}

\begin{abstract}
:
The purpose of this paper is to analyze the realization of Partnership and Community Development Program as stipulated by the regulations of State-Owned Enterprises Minister and whether they have effect on financial performance and firm risk. The regulations require State-Owned Enterprises to allocate $2 \%$ of net income for each of the following programs: Partnership Program and Community Development Programs. The research design is quantitave method. Data are collected from Sustainability Reports and Annual Reports published by State-Owned Enterprises for the period of 2007 to 2017. The results of hypothesis test indicate that Partnership Program does not influence financial performance and firm risk. Meanwhile, Community Development Program has a significant and positive effect on financial performance. Furthermore, Community Development Program has a significant and negative effect on firm risk.
\end{abstract}

Keywords: partnership program, community development program, state-owned enterprises, financial performance, firm risk

DOI: $10.7176 /$ RJFA/10-20-10

Publication date:October $31^{\text {st }} 2019$

\section{Introduction}

State-Owned Enterprises (SOEs) is one of the national economic actors as stipulated by Law Number 19 of 2003 concerning State-Owned Enterprises (SOEs) in Indonesia. The existence of SOEs is intended to contribute to the development of national economy, to hold general benefit in the form of providing goods and services for the fulfillment of the livelihood of the people and become a pioneer of business activities that can not be implemented by the private sector and cooperatives. CSR programs have started to emerge in Indonesia as Law No. 40 of 2007 on Limited Liability Company and Act no. 25 of 2007 on Investment.

Partnership Program (PP) and Community Development Program (CDP) are mandated to SOEs as types of company's contribution to society and environment. Based on SOEs Minister Regulation no. Per-05/MBU/2007, the partnership program of SOEs with Small Business is a program to increase the ability of small-scale enterprises to become tough and independent through the utilization of funds from the SOEs' profit. Meanwhile, the Community Development program is a program of environment social empowerment by state-owned enterprises through the utilization of funds from the share of SOE's profit. The assisted partner companies as referred to Per05 in 2007 are small businesses that get loans from the Partnership Program. The small business is independent, not a subsidiary or branch of a company owned or affiliated either directly or indirectly with medium or large business. The characteristic of a business entity may be an individual business, a non-legal entity, or a legal entity.

Regulation of the Minister of SOEs no. Per-05/MBU/2007 on Partnership Program with Small Business and Community Development Program serve as a reference analysis in this study. The consideration is that the allowance for Partnership Program and Community Development Program of $2 \%$ of profit after tax (net profit) is determined by the SOEs regulation. Although it has been revised 4 times with Per-20/MBU/2012, Per05/MBU/2013, Per-07/MBU/2013, and Per-08/MBU/2013, however the budget tariff for Partnership Program and Community Development Program did not change: $2 \%$ of net income respectively.

Considering the importance of the role of SOEs in improving the capability of small-scale enterprises and the empowerment of social conditions of society and the environment, this study aims to analyze whether SOEs have realized an allowance for $2 \%$ of net income as stipulated and mandated by Per-05 in 2007 for each program which 
is the Partnership Program and its Community development program that the percentage is determined by the Minister and also for the State-Owned Enterprise in the form of Limited Liability Company (Article 9 paragraph 3 Per-05/MBU 2007).

The liability of SOEs on CSR activities is different between various countries. In China, CSR is clearly stipulated by the central government that SOEs must bear the necessary social responsibility which has been explicitly states on the Management Law of State-Owned Assets (Liu, 2009). Study conducted by Xu and Zeng (2015) indicates that state ownership companies are positively associated with CSR. The following are examples in other countries (Christiansen, 2013). In Netherland, all SOEs are required to apply GRI reporting. In Hungary, there is no overarching approach for CSR activities, large SOEs are expected to perform well of CSR activities compared to similar private firms. In New Zealand, CSR targets exceeding those of most private companies included in SOEs performance requirements. In the U.S, SOEs are encouraged to involve in CSR activities (Liu, 2009). As a comparison, countries' law previously discussed do not specifically regulate the obligation to allocate a part of the profit gained for CSR activities as it is explicitly required for SOEs in Indonesia.

The most important issue to be examined is whether Partnership Program and Community Development Program activities realized by SOEs have an impact on the financial performance and firm risk. Partnership Program and Community Development Program are types of CSR program conducted by SOE. Several studies have linked CSR relationships with firm performance (Orlitzky and Benjamin, 2001; Kempf and Osthoff, 2007; Surroca et al. 2010; Melo, 2012; Sadeghi, 2015; Tuppura, 2016; and Chrourou and Triki, 2017). Other studies also linked CSR to the risks facing the company. Some of these studies were conducted by Nguyen and Nguyen (2013), Lee (2016), Hsu and Chen (2015), Orlitzky and Benjamin (2001), Godfrey (2005), Sen et al (2006), and Melo (2012).

The significance of this study is not all countries require state-owned companies to set aside their profits on CSR activities such as partnership program and community development program. Even in Indonesia, this study is very limited. The results of this study would contribute insight to the literature and to the regulator to enhance the role of SOEs in Partnership Program and Community Development Program activities. Partnership Program and Community Development Program as a type of CSR turned out not only positive impact for small businesses and communities but also improve the financial performance of SOEs and reduce firm risk. Next section of this paper discusses literature review and hypothesis development, research method, result and discussion, and conclusion.

\section{Literature Review and Hypothesis Development}

\subsection{Partnership Program and Community Development Program as CSR of State-Owned Enterprises (SOEs)}

Legitimacy is a general perception or assumption that the actions taken by an entity are desirable or appropriate to a system of socially developed norms, values, beliefs and definitions (Suchman, 1995). Many companies hope to operate in accordance with social desires because social legitimacy to the company becomes a strategic factor for the development of the company (Ashfor and Gibbs, 1990). However, maintaining this legitimacy is not easy because legitimacy is a dynamic construct. Environment expectations are not static, but always change in response to the environment in which the company operates. Therefore, a company that does not alter its viewpoints and activities will lose its legitimacy despite previously obtaining legitimacy (Deegan et al 2002).

Stakeholder theory is the relationship between stakeholders and information received (Hill and Jones, 1992). The company is not an entity operating for its own sake, but must benefit all its stakeholders. Freeman and Ve (2001) argue that companies should pay attention to efforts to maintain good relationships with stakeholders who are social and community elements without their support the company cannot maintain its sustainability.

Partnership Program and Community Development Program is one of the instruments to realize SOEs social responsibility (CSR). As regulated in the Regulation of the Minister of SOEs no. 20/MBU/2012 on Partnership and Community development Program that Partnership Program of SOEs with Small Business is a program to improve the ability of small-scale enterprises to become tough and independent through the utilization of a portion of the profit of SOEs. Partnership here means accompanied by coaching and development by medium and / or large enterprises with the principle of mutual need, strengthening, and profitable.

Partnership programs are provided in several forms, namely loans for working capital or purchases of fixed assets in order to increase production and sales. Special loans are for short-term business funding needs to fulfill orders from suppliers of assisted partners. Another form of grant financing is used for education, training, apprenticeship, marketing, promotion related to enhancing the productivity of the target partners as well as research 
related to the partnership program. The performance of Partnership Program has been determined in the Minister of SOE Regulation no. Per-10/MBU/2014 on indicators of rating of State-Owned Enterprises Financial Services, Insurance Business Sector, and Guarantee Services which is based on the effectiveness of the absorption of funds and the level of collectability. Meanwhile, performance of SOEs except financial service companies is still regulated in the Decree of the Minister of SOEs. Kep-100 / MBU / 2002 dated June 4, 2002 on the rating of health of SOEs.

Community Development Program is a program of empowerment of social condition of society by SOEs through utilization of fund from part of profit earned by SOEs. The scope of BL program assistance is in the form of natural disaster, education and /or training, health improvement, infrastructure and/or public facilities development, religious service, and nature conservation, and social assistance for poverty alleviation (Per-08 / MBU / 2013). Regulation of the Minister of SOEs no. Per-05 / MBU / 2007 on Partnership Program BUMN with Small Business and Community Development Program (PKBL) serve as a reference analysis in this study. The consideration is that the allowance for PKBL of $2 \%$ of profit after tax (net profit) is to be determined by this SOE regulation. Although it has been revised 4 times with Per-20/ MBU/2012, Per-05/MBU/2013, Per-07/ MBU/2013, and Per-08/MBU/2013, however the tariff of budget funds for Partnership Program and Community Development did not change: $2 \%$ of net income respectively.

\subsection{CSR and Financial Performance}

Carroll (1999) defined there are four components that describe the CSR pyramid as a form of corporate social responsibility that is generating profit as the foundation of responsibility (economic responsibility), complying with the rules (legal responsibility), the responsibility to do what is right and fair (ethical responsibility), and become good corporate citizenship, contributing to the environment, and developing a quality of life (philanthropic responsibility). Elkinton (2007) suggested the concept of Triple Bottom Line (People, Planet, Profit) as a form of Corporate Social Responsibility (CSR), the company set aside a portion of its profits for the sustainable development of people and the environment. The latest international regulation on CSR namely International Standardization of Organization (ISO) 26000 formulates the following CSR. CSR is the responsibility of an organization for the impact of decisions and activities of an organization for its society and its environment, through transparent and ethical behavior consistent with sustainable development and environment welfare. Taking into account the expectations of its stakeholders, in line with applicable law and attitude norms and also integrated to the whole organization.

Partnership Program and Community Development Program an instrument of embodiment of social responsibility (CSR) that must be implemented by all SOEs. The researches linking CSR to financial performance have been conducted by Kempf and Osthoff (2007), Surroca et al (2010), Quazi and Richardson (2012), and Melo (2012). Quazi and Richardson (2012) performed a meta-analysis of csr relationships and financial performance. They found that sample size and statistical methods were an important source of variations in measuring the relationship between CSR and the financial performance of 51 publications reviewed.

Sadeghi (2015) who took a sample of research on firms in Tehran Stock Exchange revealed that the company's social performance for customers had a negative effect on the firm's ROA; in the meantime, the social performance dimension for employees or workers has a positive influence on ROA. US research conducted by Tuppura et al (2016) for the food, energy, forest and clothing industries found that there is a two-way causal relationship between CSR performance and financial performance. Furthermore, Chrourou and Triki (2017) whose study related companies in Tunisia prove that there is a positive influence of philanthropic CSR on financial performance. Based on the above explanation, the following hypotheses are defined.

\section{H1. Partnership Program and Community Development Program enhance SOEs' Financial Performance}

\subsection{CSR and Risk}

CSR practices and reporting are related to the concept of reputation risk management (Bebbington, 2007). Reputation risk management can help in understanding what motivates the quantity and quality of CSR reporting. Hogan and Lodhia (2011) explained it is "honesty" as a potential strategy for reputation risk management. However, Furthermore, Dowling (2016) affirmed that the size for CSR's reputation still needs to be determined and developed.

Research connecting CSR and firm risk was conducted by Nguyen and Nguyen (2013). Lee (2016) noted that CSR significantly reduces the risk of "crash" share prices in Taiwan. Later, companies involved in CSR typically perform better within the context of credit ratings and have lower credit risk (Hsu and Chen, 2015). CSR 
can reduce the likelihood of incidents or incidents such as air pollution and pollution of factory waste which is a goodwill that can aggravate companies from public demand (Orlitzky and Benjamin, 2001).

Through involvement in CSR activities, good relationships established among stakeholders result in companies with the same protection as insurance contracts (Godfrey, 2005). Investment in CSR helps companies to reduce risks (Donaldson and Preston, 1995; and Jones, 1995). CSR creates goodwill that can reduce negative ratings of Stakeholders (Sen et al, 2006). Larger customer loyalty can help companies absorb external complaints and allow time for companies to change their operations.

CSR can improve employee behavior towards companies and make them willing to share company problems such as financial difficulties (Melo, 2012). Besides helping to absorb the influence of negative judgments, CSR can reduce the likelihood of companies experiencing community violations (Nguyen and Nguyen 2013). Based on the above argumentation, the research hypothesis is set forth below.

\section{H2. Partnership Program and Community Development Program reduce firm risk}

\subsection{Firm Size and Leverage}

In addition to partnership and community development program variables, we include control variables considered to be associated with financial performance and firm risk. Specifically, we include firm size and leverage. Dang et al (2017) confirm that the most popular proxiest of firm size are based on natural logarithm forms of the following three firm size measures: total assets, total sales, and market value of equity. Beck et al (2005) argue that firm size is related to a firm's productivity, survival, and profitability. Youn et al (2015) support the viewpoint that larger firms have more resources than smaller firms; therefore, they tend to develop and implement CSR initiatives better than smaller firms. In addition, Chtourou dan Triki (2017) argue that large firms are able to generate better financial performance than small-sized firms by their power at the level of access to resources and by achieving economies of scale. Thus firm size has a positive effect on financial performance.

Abdullahi et al (2011) argue that size of firm or sector does not have significant influence on the sectoral risks. Lee (2016) exhibits that larger firm size are significantly and positively associated with higher future crask risk in the Asian emerging stock market of Taiwan firms. Meanwhile, Nguyen and Nguyen (2013) demonstrate that firm size has a negative influence on firm risk. Thus, firm size has a negative influence on firm risk.

Horne and Wachowicz (2012) confirm that financial leverage or debt to equity ratio is to assess the extent to which the firm using borrowed money; the lower the ratio, the higher the level of the firm's financing that is being provided by shareholders. Surroca et al (2010) demonstrate that financial leverage does not influence corporate financial performance. In addition, Chtourou and Triki (2016) also exhibited that financial leverage do not have association with financial performance. Thus, financial leverage does not have effect on financial performance.

Lee (2016) argues that financial leverage does not have impact on reducing crash risk in the Asian emerging stock market of Taiwan firms. Firms which have high levels of financial leverage were proved to have lower idiosyncratic risk reduction (Mishra and Mode, 2013). However, Nguyen and Nguyen (2013) demonstrate that financial leverage has a negative influence on firm risk. Thus, leverage has a negative effect on financial performance.

\section{Research Methods}

\subsection{Sample Selection}

The research population was all State-Owned Enterprises (SOEs) which amounted to 119 companies as presented on the official web of the Ministry of SOE: http://www.bumn.go.id, over the period of 2007-2017. The study is started from 2007 because Partnership Program and Community Development Program have been mandated to implement since 2007. To obtain a representative sample, the method used is purposive sample. The sample criteria are as follows: SOEs present separate Sustainability Report; If SOEs did not publish separate sustainability report, then the information of Partnership Program and Community Development Program activities were presented or disclosed in corporate annual report. Based on the criteria, 101 companies did not present complete Partnership Program and Community Development Program information and therefore were excluded, thus reducing the number to 18 companies (180 firm-years observations). 


\subsection{Variables and Measurement}

Dependent Variable is company financial performance which is proxied with Return On Asset (ROA) and Return On Equity (ROE) ratios as used by Nguyen \& Nguyen (2013), and Luo and Bhattacharya (2009). ROA is measured by ratio Net profit divided with Total Assets and ROE is measured by ratio Net Profit divided with Total Equity. Tobin's Q as a dependent variable is also used by other researchers such as Nguyen \& Nguyen (2013) and Luo and Battcharya (2009). Tobin's Q cannot be tested in this study because of data availability. To measure using Tobin's Q model, additional data about market value of firm are needed. In fact, not all of State-owned Enterprises in Indonesia are listed in Indonesia Stock Exchange. Another dependent variabel is firm risk which is proxied with standard deviation of ROA as used by Nguyen \& Nguyen (2013); and Luo and Battacharya (2009).

Independent Variable is Partnership Program (PP) and Community Development Program (CDP) which are measured from natural logarithm of fund realized for Partnership Program (LogPP) and Community Development Program (LogCDP) of each state-owned company. The data are obtained from Company Sustainability Report or from Annual Report. Control Variables are Leverage and Firm Size. Leverage shows the total debt of the company compared to total liabilities; Firm Size is calculated from the total natural logarithm of the asset or Log (Total Assets).

Control variables consist of (1) firm size is measured with natural log of total assets (Nguyen and Nguyen, 2013; Dyreng et al, 2010); (2) lleverage is measured by total debt/total common equity (Ege, 2015; Nguyen and Nguyen, 2013).

\subsection{Data Analysis}

This study uses panel data which contain time series observations of variables of a number of firms. Heij et al (2004) argue that observations in panel or pooled data involve at least two dimensions: cross sectional dimension, indicated by subscript, and a time series dimension, indicated by subscript t. Gujarati and Porter (2012) explain that in pooled estimators, the error terms are likely to be correlated over time for a given subject. Thus, if the fixed effect model is approaproate but we use the pooled estimator then the estimated coefficients will be inconsistent. To determine the appropriate model, Green (2003) suggests the following steps should be executed: (1) to test betweeen pooled OLS and a fixed effect model, one should test the correlation between the cross-section specific effect and the dependent variable using the F-test and the Chi-Square test. If a correlation existed, the pooled OLS was inconsistent; (2) to test between the fixed effect and random effect models, one could use the Hausman specification test, which tests the correlation between unobserved individual random effects and a dependent variable. If the null hypothesis was rejected, then the random effect model was inconsistent, hence use the fixed effect model. The panel data are analyzed using EViews 8. To test which model is better, Widarjono (2013) explains the following tests, namely: Chow test, Hausman test, and Langrange Multiplier (LM) test.

\subsection{Research Models}

Model for $\mathrm{H}_{1}$

FPit $=\beta_{0}+\beta_{1} P P+\beta_{2} C_{\text {DP }}+\beta_{3}$ Size $_{i t}+\beta_{4} \operatorname{Lev}_{\text {it }}+\varepsilon$

where FPit is financial performance $\mathrm{i}$ in year $\mathrm{t}$; PP \& CDP are parthership program and community development program $i$ in year $t$; and $\varepsilon$ is residual error in year $t$.

Model for $\mathrm{H}_{2}$

$\mathrm{FR}_{\mathrm{it}}=\beta_{0}+\beta_{1} \mathrm{PP}+\beta_{2} \mathrm{CDP}$ it $+\beta_{3} \mathrm{Size}_{\mathrm{it}}+\boldsymbol{\beta}_{4} \mathrm{Lev}_{\text {it }}+\varepsilon$

where FRit is firm risk i in year t; PP \& CDP are parthership program and community development program $i$ in year $\mathrm{t}$; and $\varepsilon$ is residual error in year $\mathrm{t}$.

\section{Results and Discussion}

\subsection{Descriptive Statistics}

Table 2 shows that partnership program and community development program (PP\&CDP) and Size have a relatively high standard deviation as compared to the mean. Indicated that sample variability for PP\&CDP is quite high. Each variable of firm performance which is proxied by ROA and ROE, firm risk, and leverage has quite the same value both in average and standard deviation; this means that each firm in the sample are homogeneous and low variability. 
Table 1 Descriptive Statistics.

\begin{tabular}{lccccc}
\hline \multicolumn{1}{c}{ Variables } & Mean & Median & Max & Min & Std Dev \\
\hline $\begin{array}{l}\text { Partnership and Community } \\
\text { Dev. Program }\end{array}$ & 93.26 & 45.96 & 964.68 & 0.72 & 138.56 \\
ROA & 0.07 & 0.05 & 0.34 & -0.09 & 0.07 \\
ROE & 0.01 & 0.00 & 0.03 & 0.01 & 0.00 \\
Firm Risk & 0.02 & 0.01 & 0.13 & 0.03 \\
Leverage & 2.90 & 1.34 & 13.62 & 0.03 & 3.33 \\
Size & 13.43 & 13.31 & 13.62 & 0.03 & 3.32 \\
\hline
\end{tabular}

\subsection{The results of Hypothesis 1}

Model selection test is conducted to decide which model is suitable for regression model estimator. Chow test and Hausman test were undertaken. Results of the test conclude that the selected model is a fixed effect.

Table 3 shows that the variable has a significance level of 0.0005 for ROA and 0.0135 for ROE which are under $1 \%$. This result indicates that community development program has a significant and positive effect on the financial performance of the company. In other words, the greater the realization of corporate spending for community development program, the higher the company's financial performance. The results of this study are consistent with last researches in other countries conduceted by Sadeghi (2015) in Tehran Iran, Tuppura et al (2016) in U.S and Chourou and Triki (2017) in Turkey.

Partnership program proved to have no effect on financial performance. The significant level of partnership program is above 5\% (0.5666 for ROA and 0.5558 for ROE). The following facts support this results. Firstly, partnership program is a program designed specifically for Micro, Small, and Medium enterprise to be sustainable, self-sufficient and have competitive power using funds benefit from BUMN profits. The benefits of this funding depend on the accuracy of the distribution to Micro, Small, and Medium Enterprises in need (Pratama, 2013). Secondly, In the Ministerial Regulation of State-Owned Enterprises No. PER-05 / MBU / 2007 concerning Partnership Program of State-Owned Enterprises with Small Enterprises and Community Development Program, the only accountability required is the realization of the fund. The only performance that must be measured is the effectiveness and collectability of partnership funds namely micro and small credit funds that must be returned by Micro, Small, and Medium Enterprises to SOE. Therefore, Partnership program has no direct benefits to the society which in turn will increase SOE reputation (Angela and Widyawati, 2014)...

Control variables such as Size has a significant and positive effects on ROA and ROE. Meanwhile, leverage did not have an effect on ROA and ROE. The test results also show that Adj $\mathrm{R}^{2}$ is high enough that is equal to $75 \%$ for ROA and $78 \%$ for ROE. The number of adj $\mathrm{R}^{2}$ indicates that variable ROA and ROE can be respectively explained by $75 \%$ and $78 \%$ of the independent variables studied.

\subsection{The results of Hypothesis 2}

Model selection test is also conducted to decide which model is appropriate for regression model estimator. Chow test and Hausman test were undertaken. Results of the test conclude that the selected model is a random effect.

Result of hypothesis test 2 is shown in Table 4 . The result proves that community development program has a significant and negative effect on firm risk with a level of significance that is under $1 \%(0,0034)$; the greater realization of corporate expenditure for community development program, the lower the company risk. The results of this study were consistent with research conducted in other countries namely Nguyen and Nguyen (2013) against companies in U.S, Melo (2012), Sen et al (2006), Lee (2016), and Hsu and Chen (2015).

Meanwhile, partnership program provides contrast result which indicates no effect on firm risk. The significant level of partnership program is above 5\% (0.4945). The reason is the same as previously explained in hypothesis 1 analysis and discussion. Partnership programs do not provide immediate and direct benefits to the society as compared to community development program (Angela and Widyawati, 2014). 
Table 2 Regression results of research model 1.

\begin{tabular}{|c|c|c|c|c|c|}
\hline \multirow[b]{2}{*}{ Variables } & \multirow[b]{2}{*}{$\begin{array}{l}\text { Predicted } \\
\text { Sign }\end{array}$} & \multicolumn{2}{|c|}{ ROA } & \multicolumn{2}{|c|}{ ROE } \\
\hline & & Coefficients & Sig. & Coefficients & Sig. \\
\hline (Constant) & $+/-$ & 1.1267 & 0.0000 & 0.0056 & 0.0000 \\
\hline PP & + & 0.0035 & 0.5666 & 0.8250 & 0.5558 \\
\hline CDP & + & 0.0237 & $0.0005 * * *$ & 0.0005 & $0.0135^{* *}$ \\
\hline SIZE & + & -0.0344 & $0.0000 * * *$ & 0.3903 & $0.0001 * * *$ \\
\hline LEV & - & -0.0057 & $0.0174 * *$ & -0.3304 & $0.0012^{* * *}$ \\
\hline $\mathrm{N}$ & & \multicolumn{2}{|c|}{18} & \multicolumn{2}{|c|}{18} \\
\hline $\mathrm{F}$ & & \multicolumn{2}{|c|}{22.6733} & \multicolumn{2}{|c|}{30.903} \\
\hline Sig F & & \multicolumn{2}{|c|}{0.0000} & \multicolumn{2}{|c|}{0.0000} \\
\hline Adj R2 & & \multicolumn{2}{|c|}{0.75} & \multicolumn{2}{|c|}{0.78} \\
\hline
\end{tabular}

***Significant at 1 percent; $* *$ Significant at 5 percent; $*$ Significant at $10 \%$

Note $: \mathrm{PP}=$ Partnership Program; CDP $=$ Community Development Program; Size=Natural log of total assets; LEV=Leverage

Control variables are also examined against corporate risk. Size proved to have a significant influence on the level of $1 \%$ with a positive direction on corporate risk. Meanwhile, LEV has significant level about $5 \%$ (0.2243). Therefore, it can be concluded that LEV has no effect on firm risk.

Table 3 Regression results of research model 2.

\begin{tabular}{cccc}
\hline \multicolumn{4}{c}{ Dependent Variable: Firm Risk } \\
\hline Variables & Predicted Sign & Coefficients & Sig. \\
\hline (Constant) & $+/-$ & 0.3142 & 0.0000 \\
PP & - & 0.0023 & 0.4945 \\
CDP & - & 0.0109 & $0.0034^{* * *}$ \\
LEV & + & -0.0009 & 0.2243 \\
SIZE & + & -0.0098 & $0.0000^{* * *}$ \\
\hline N & & 18 & \\
F & & 18.8493 & \\
Sig F & 0.0000 & \\
Adj R2 & & 0.29 &
\end{tabular}

***Significat at 1 percent; $* *$ Significant at 5 percent; $*$ Significant at $10 \%$

Note : $\mathrm{PP}=$ Partnership Program; $\mathrm{CDP}=$ Community Development Program; Size=Natural $\log$ of total assets; LEV=Leverage

\section{Conclusion}

The result shows the Regulation of Minister of SOE through Per-05/ MBU/2007 concerning Partnership Program and Community Development Program have not been effectively implemented. The results of this study provide empirical evidence that the realization for Community Development conducted by SOEs have a positive effect on the improvement of corporate financial performance such as ROA and ROE. In addition, Community Development Program can also mitigate firm risk. Meanwhile, partnership program provide different result. It does not have significant effects on alleviating firm performance. Furthermore, partnership program does not either have effects on mitigating firm risk. 
This study has limitations on data and information of Partnership and Community Development Program activities. Among 119 SOEs, it was only $18 \%$ or 22 companies that published separate Sustainability Report. However, this research only uses sample of 18 SOEs (15\% from total 119 company). For further research it is suggested to use data of all state-owned enterprises by way of officially cooperation with the Office of the Ministry of SOEs.

\section{References}

Abdullahi, L.B., Lawal, W.A. and Eudaiye-Muhtar, O.F. (2011). The effects of firm size on risk and return in the Nigerian Stock Market: A Sectoral Analysis, British Journal of Economics, Finance and Management Science 1 (2): $1-10$.

Angela, R. V. and Widyawati, D. (2014). Efektivitas Penyaluran Dana Corporate Social Responsibility Sebagai Bentuk Akuntabilitas Publik, Jurnal Ilmu \& Riset Akuntansi 3 (6): 1-15.

Ashford, B, E, and Gibbs, W. (1990). The Double-Ege of Organizational Legitimation, Organization Science 1 (2): 177-194.

Bebbington, J. And Larrinaga, C. (2008). Corpoarate social reporing and reputation risk management, accounting, Auditing \& Accountability Journal 21 (3): 337-361.

Beck, T., Kunt, A.D. and Maksimovic, V. (2005). Financial and Legal Constraints to Growth: Does Firm Size Matter, Journal of Finance LX (1): 137-177.

Caroll, A. B. (1999). “Corporate Social Responsibility: Evolution of a Definitional Construct.” Business Society. 38 (3): 268-295.

Chtourou, H. and Triki, M. (2017). Commitment in csr and financial performance: a study in the Tunisian context, Social Responsibility Journal, 13 (2): 370-389.

Christiansen, H. (2013). "Balancing Commercial and Non-Commercial Priorities of State-Owned Enterprises",

OECD Corporate Governance Working Papers, No. 6, OECD Publishing. (http://dx.doi.org/10.1787/5k4dkhztkp9r-en).

Dang, C., Li, Z. and Yang, C. (2017). Measuring Firm Size in Empirical Corporate Finance. Journal of Banking and Finance. Doi:10.1016/j-jbankfin.2017.09.0006.

Deegan, C., Rankin, M. and Tobin, J. (2002). “An Examination of the Corporate Social and Environmental Disclosures of BHP from 1983-1997: A Test of Legitimacy Theory." Accounting, Auditing, and Accountability Journal 15 (3): 312-343.

Donaldson, T. and Preston, L.E. (1995), The stakeholder theory of the corporation: concents, evidenc, and implications, Academy of Management Review 20 (1): 65-91.

Dowling, G. (2016). Defining and Measuring Corporate Social Reputations, Annals in Social Responsibility 2 (1): 18-28.

Dyreng, S. D., Hanlon, M. and Maydew, E. L. (2010). The Effects of Executives on Corporate Tax Avoidance, The Accounting Review 85 (4): 1163-1189.

Ege, S. M. (2015). Does Internal Audit Function Quality Deter Management Misconduct. The Accounting Review 90 (2): 495-527.

Elkington, J. (2007). Cannibals With Forks, the Tripple Botton Line of Twentieth Century Business Capstone: Oxford.

Freeman, R.E., and Vea J.M. (2001). “A Stakeholder Approach to Strategic Management.”. (http://www.ssrn.com , accessed at Dec 27, 2016).

Godfrey, P. (2005). The relationship between corporate philanthropy and shareholder wealth: a risk management perspective, Academy of Management Review 30 (4): 777-798.

Greene, W. H. (2003). Econometric Analysis. $5^{\text {th }}$ ed. New Jersey: Prentice Hall.

Gujarati, D. N., and Porter, D. C. (2009). Basic Econometrics. New York: McGraw-Hill

Heij, C., Boer, P. D. Franses., P.H. Kloek, T. and Dijk, H. K. V. (2004). Econometric Methods with Applications in Business and Economics. New York: Oxford University Press.

Hill, C.W. and Jones, T.M. (1992). "Stakeholder Agency Theory.” Journal of Management Studies 29: 131-154. 
Hogan, J. And Lodhia, S. (2011). Sustainability reporting and reputation risk management: an Australian case study, International Journal of Accounting and Information Management 19 (3): 267-287.

Hsu, F. J. and Chen, Y. (2015). Is a firm's financial risk associated with corporate social responsibility, Managerial Decision 53 (9): 2175-2199.

Jones, T.M. (1995). Instrumental stakeholder theory: a synthesis of ethics and economics, Academy of Management Review 20 (2): 404-437.

Kempf, A. And Osthoff, P. (2007). The effect of socially responsible investing on financial performance, European Financial Management 13 (5): 908-922.

Law of The Republic of Indonesia No. 19 concerning State-Owned Entities, enacted in Jakarta on June 19, 2003.

Law of The Republic of Indonesia No. 40 concerning Limited Liability Companies, enacted in Jakarta on August 16, 2007.

Law of the Republic of Indonesia No. 25 concerning Investment, enacted in Jakarta on April 26, 2007.

Lee, M. (2016). Corporate social responsibility and stock price crash risk, Managerial Finance 42 (10): 963-979.

Liu, Y. (2009). A Comparison of China's State-Owned Enterprises and Their Counterparts in the United States: Performance and Regulatory Policy, Public Administration Review, Special Issue 69: S46-S52

Luo, X. and Bhattacharya, C.B. (2009) The Debate over Doing Good: Corporate Social Performance, Strategic Marketing Levers, and Firm-Idiosyncratic Risk. Journal of Marketing 73 (6): 198-213.

Melo, T. (2012). Determinants of corporate social performance: the influence of organizational culture, management tenure and financial performance, Social Responsibility Journal 8 (1): 33-47.

Nguyen, P. and Nguyen, A.. (2013). The Effect of Corporate Social Responsibility on Firm Risk, Social Responsibility Journal 11 (2): 324-339.

Orlitzky, M. and Benjamin, J. D. (2001). Corporate Social Performance and Firm Risk: A Meta-Analytic Review. Business \& Society 40 (4): 369-396.

Pratama, M. A. (2013). Analisis Efektivitas CSR dalam Program Kemitraan BUMN. Jurnal Natapraja 1 (1): $105-$ 113.

Quazi, A. Dan Richardson, A. (2012). Sources of variation in linking corporate social responsibility and financial performance, Social Responsibility Journal 8 (2): 242-256.

Regulation of the Minister of SOEs No. 100/MBU/2002 dated at 4 June 2002 concerning the assessment of health level of SOEs.

Regulation of the Minister of SOEs No. Per-05/MBU/2007 concerning Partnership Program of SOEs with small companies and Environmental Development Program.

Regulation of the Minister of SOEs No. Per-20/MBU/2012 concerning the changes to the regulation of the minister of SOEs No. Per-05/MBU/2007 concering Partnership Program with small companies and Environmental Development Program.

Regulation of the Minister of SOEs No. : Per-05/MBU/2013 concerning the second change to the regulation of Per-05/MBU/2007 dated at 27 April 2007 concerning Partnership Program with small companies and Environmental Development Program.

Regulation of the Minister of SOEs No. Per-07/MBU/2013 concerning the third change to the regulation of the minister of SOEs No. Per-05/MBU/2007 concerning Partnership Program with small companies and Environmental Development Program which have been changed the Minister of SOEs regulation No. Per20/MBU/2012 dated at 27 Desember 2012 and the regulation of minister of SOEs No. Per-05/MBU/2013 dated at 1 Mei 2013.

Regulation of the Minister of SOEs No. Per-08/MBU/2013 concerning the fourth change to the regulation of the minister of SOEs No. Per-05/MBU/2007 concerning Partnership Program with small companies and Environmental Development Program.

Regulation of the Minister of SOEs No. Per-10/MBU/2014 concerning indicators for assessing the level of health of State-owned enterprises which business activities deal with financial services, insurance business, and guarantee services. 
Sadeghi, G. (2015). Impact of corporate social performance on financial performance of manufacturing companies (IMC) listed on the Tehran Stock Exchange, International Journal of Law and Management 58 (6): 634-659.

Sen, S., Bhattacharya, C. B, dan Korschun, D. (2006). The role of corporate social responsibility in strengthening multiple stakeholder relationships, Journal of the Academy of Marketing Science, Vol 34 No. 2, pp 158-166.

Suchman, M. C. (1995). "Managing Legitimacy: Strategic and Institutional Approaches". Academy of Management Journal 20 (3): 571-610.

Surroca, J., Tribo, J.A, dan Waddock, S. (2010). Corporate Responsibility and financial performance: the role of intangible resources, Strategic Management Journal 31 (5): 463-490.

Tuppura, A., Arminen, H., Patari, S. and Jantunen, A. (2016). Corporate social and financial performance in different industry contexts: the chicken or the egg?. Corporate Social Responsibility 12 (4): 672-686.

Widarjono, A. (2013). Ekonometrika: Pengantar dan Aplikasi, Ekonisia: Jakarta.

$\mathrm{Xu}, \mathrm{B}$. and Zeng, T. (2014). Profitability, state ownership, tax reporting and CSR: evidence from Chinese listed firms, Social Responsibility Journal 12 (1): 23-31.

Youn, H., Hua, N. and Lee, S. (2015). Does Size matter? Corporate social responsibility and firm performance in the restaurant industry. International journal of hospitality management 51: 127-134. 